\title{
LEACHING OF STEEL-MAKING WASTES IN ORGANIC ACIDS
}

\author{
1'̌́árka LANGOVÁ, ${ }^{1}$ Dalibor MATÝSEK \\ ${ }^{1}$ VŠB - Technical University of Ostrava, 17. listopadu 15/2172, Ostrava 708 33, Czech Republic, EU, \\ sarka.langova@vsb.cz, dalibor.matysek@vsb.cz
}

https://doi.org/10.37904/metal.2020.3440

\begin{abstract}
Steelmaking dust and sludge are hazardous waste materials containing leachable compounds of zinc, lead, cadmium, and other environmentally harmful elements. In this study, acetic and butyric acid were used as leaching reagents to remove easily soluble zincite selectively. The effect of the acid concentration, liquid/solid ratio, temperature and time on the metal extraction and selectivity were studied. The results for the acetic and butyric are similar. Zincite can be selectively removed using diluted acids. Most of calcium was also leached. Zinc ferrite remained in the solid residuum. The selectivity decreases with the increasing time, temperature and acid concentration. The leach liquor can be used for the preparation of nanomaterials for photocatalysis. The solid residue will be studied using the electrochemical methods and thermal analysis with the view of finding some application.
\end{abstract}

Keywords: Steel-making wastes, acetic acid, leaching, zinc

\section{INTRODUCTION}

Steel-making wastes contain zinc either in the form of an easily soluble zincite $\mathrm{ZnO}$ or hardly soluble zinc ferrite. Because of the easily leachable heavy metals as zinc, lead, cadmium etc. they are classified as the hazardous wastes. If these materials are leached at the atmospheric pressure, zincite can be dissolved in $\mathrm{NaOH}$ [1], $\mathrm{NH}_{4} \mathrm{Cl},\left(\mathrm{NH}_{4}\right)_{2} \mathrm{CO}_{3}$ [2,3]. Zinc ferrite remains in the solid residue. During the acid leaching, e.g. in hydrochloric or sulphuric acid, zinc ferrite can be dissolved, too, but iron is also contained in the solution [4-6]. Zinc can be produced by the electrolysis. More noble metals as cadmium or lead can be removed by cementation. Iron must be precipitated e.g. in the form of jarosite, goethite or hematite or extracted by various organic agents. Good results were obtained in [7] using butyric acid but this compound is very expensive. Zinc can be gained from zinc ferrite under the elevated pressure [8] or by roasting $[9,10]$. Both processes are highpriced. Zinc ferrite is widely studied as a component of a hybrid nanocomposite that exhibits superparamagnetism and for catalyzing a variety of chemical reactions [11,12]. Metallurgical waste could be a source of this material. The aim of this study was to obtain the leach liquor containing as much as possible of zinc and as few as possible of iron. Acetic acid was chosen because zinc acetate is often used for the preparation of nanomaterials.

\section{EXPERIMENTAL}

\subsection{Materials and methods}

Most of the leaching experiments were carried out at the ambient temperature $\left(22 \pm 2^{\circ} \mathrm{C}\right)$ in a shaker at 180 $\mathrm{rpm}$. Several experiments were performed at the elevated temperature. $0.1 \mathrm{~g}$ of zinc ferrite $\mathrm{ZnFe}_{2} \mathrm{O}_{4}$ or of the dried steel-making sludge from the oxygen open hearth furnace was used for the leaching experiments. The particle size was less than $0.1 \mathrm{~mm}$. The solutions of the acetic and butyric acid of various concentration and volume were used. Acetic acid was chosen a cheap leaching agent and butyric acid was tested because of the high selectivity obtained in [7]. The content of the monitored elements was determined using AAS (Varian AA280FS) and is shown in Table 1. All other elements were less than $1 \%$. The semi-quantitative mineralogical 
analysis was performed using X-ray diffraction on Bruker-AXS D8 Advance analyzer (Germany). For quantification, the Rietveld analysis in the program Bruker - Topas, version 5 was used.

Table 1 Chemical composition of the steel-making sludge (wt.\%)

\begin{tabular}{|c|c|c|c|c|c|c|c|}
\hline $\mathbf{Z n}$ & $\mathbf{F e}$ & $\mathbf{P b}$ & $\mathbf{C d}$ & $\mathbf{M g}$ & $\mathbf{C a}$ & $\mathbf{M n}$ & $\mathbf{C r}$ \\
\hline 9.5 & 54.0 & 0.72 & 0.01 & 0.33 & 0.65 & 0.91 & 0.07 \\
\hline
\end{tabular}

\section{RESULTS AND DISCUSSION}

Figure 1 presents the influence of the acetic acid concentration on zinc extraction and the selectivity, which is defined as the ratio of zinc and iron extraction. Zinc from zincite can be dissolved more easily than iron in several forms so the selectivity decreases with the increasing acid concentration. Only a few of experiments were carried out with butyric acid. These results were similar (Figure 2). If the liquid/solid ratio increases, zinc extraction rises until zincite is dissolved (Figure 3). Then iron extraction increases and selectivity falls. In case the same amount of substance of acid is available and it is sufficient for zincite dissolution, then zinc extraction is almost independent on time and acid concentration. On the other hand, selectivity decreases with increasing time and increasing acid concentration (Figure 4). The leach liquors contained also small amount of calcium, lead, cadmium, magnesium, manganese and chromium. Figures 5 and $\mathbf{6}$ show that no significant improvement was reached using butyric acid. This chemical is very expensive and it is not suitable for the wider application.

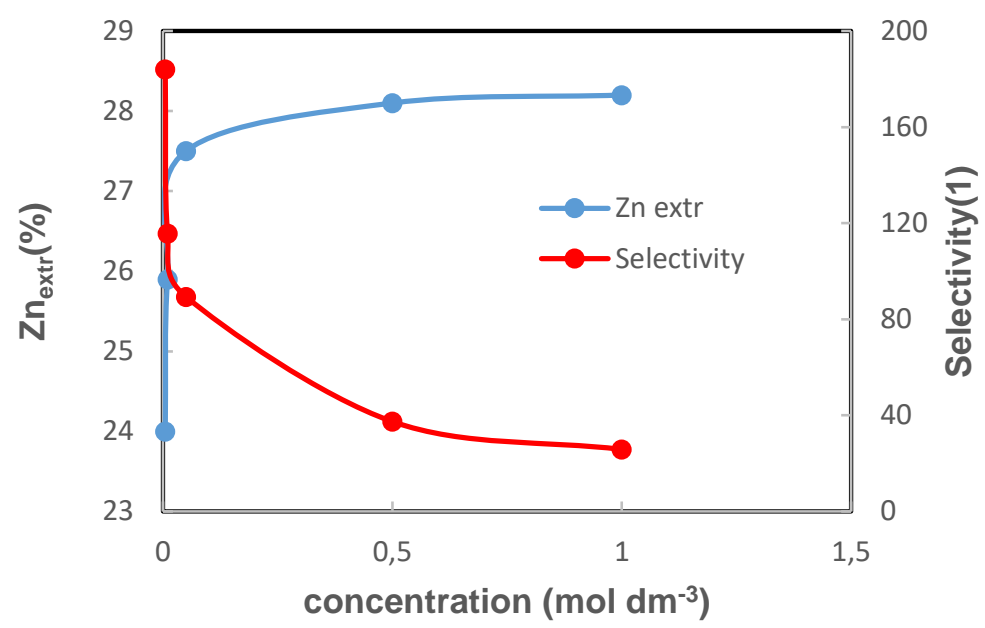

Figure 1 Concentration dependence of metal extraction from the sludge in $50 \mathrm{ml}$ of acetic acid after 3 hours

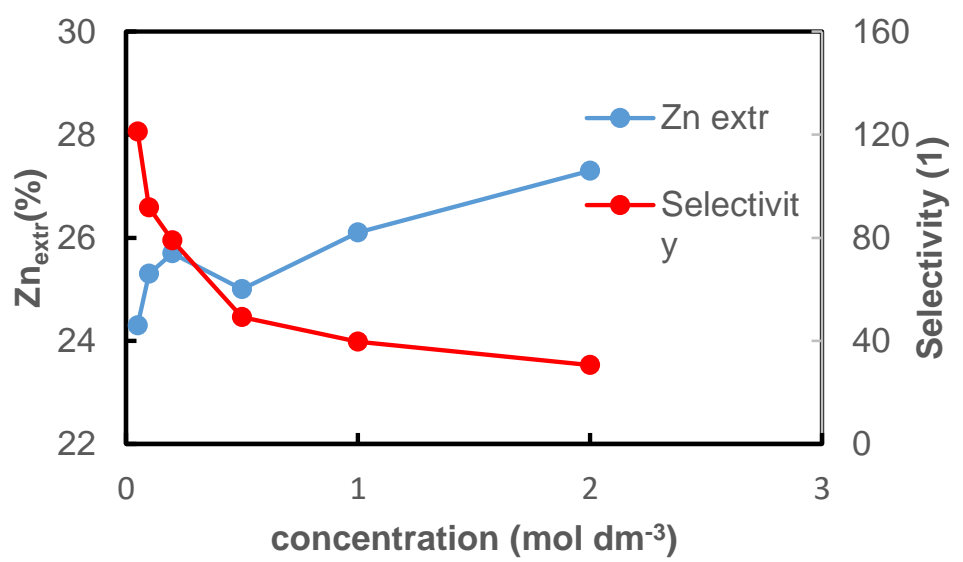

Figure 2 Concentration dependence of metal extraction from the sludge in $50 \mathrm{ml}$ of butyric acid after 3 hours 


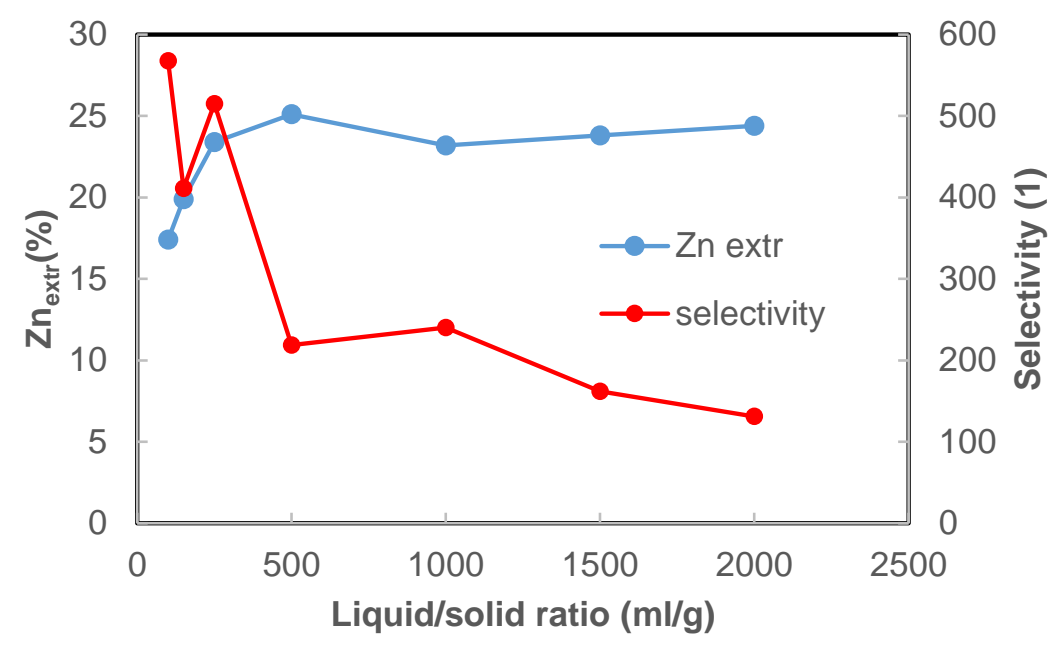

Figure 3 Effect of the liquid/solid ratio on metal extraction from the sludge and on selectivity after $3 \mathrm{~h}$ in $0.01 \mathrm{M}$ acetic acid

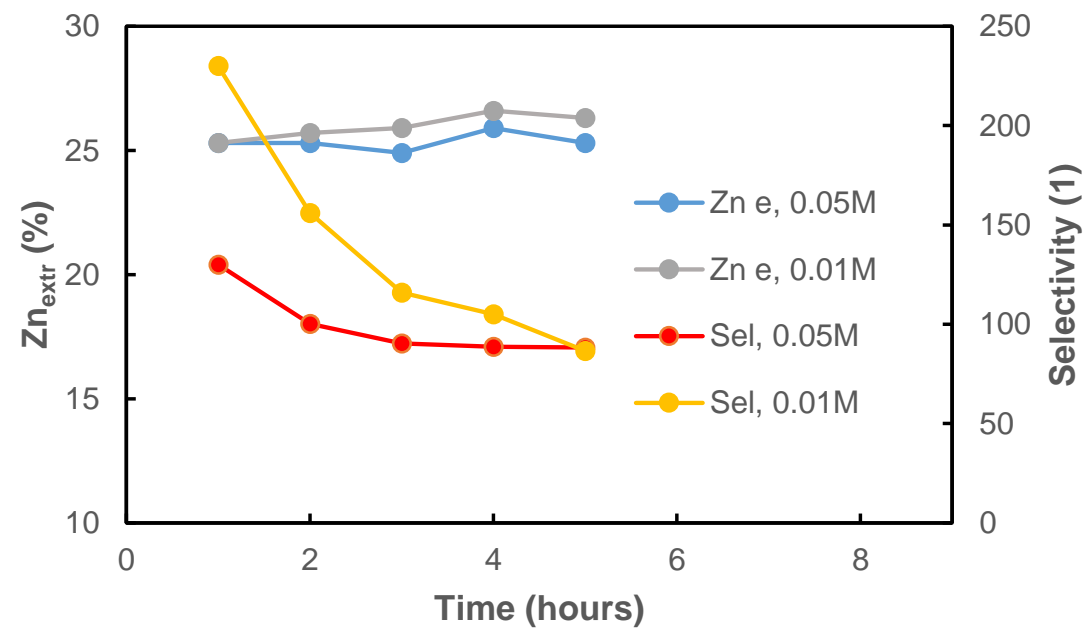

Figure 4 Time dependence of metal extraction from of TF sludge in acetic acid $-10 \mathrm{ml}$ of $0.05 \mathrm{M}$ acid; $50 \mathrm{ml}$ of $0.01 \mathrm{M}$ acid

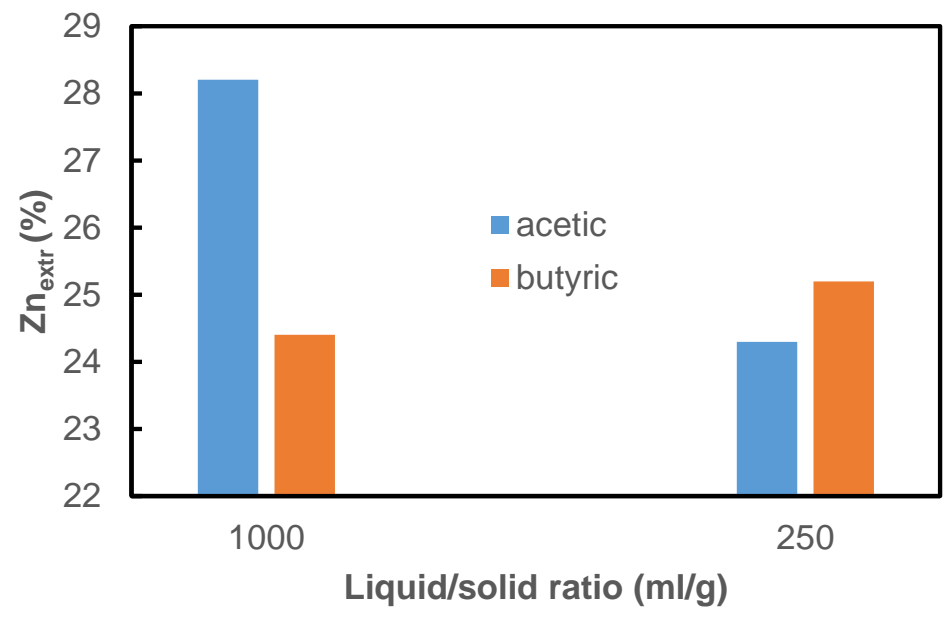

Figure 5 Leaching of the sludge in $0.01 \mathrm{M}$ acid at $22^{\circ} \mathrm{C}$ after 2 hours 


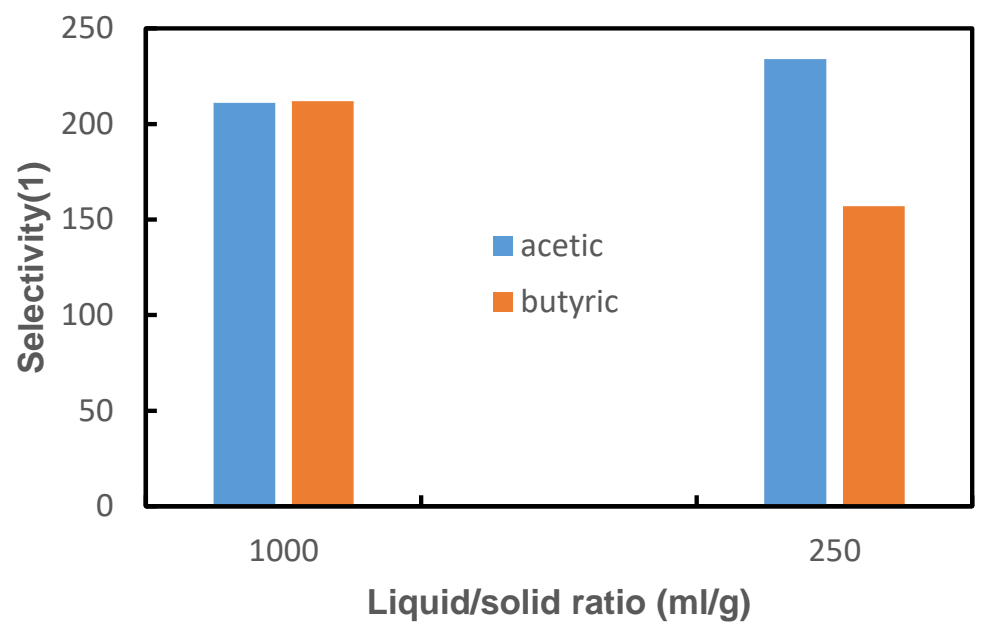

Figure 6 Leaching of the sludge in $0.01 \mathrm{M}$ acid at $22^{\circ} \mathrm{C}$ after 2 hours

The mineralogical composition of the sludge and the solid residue obtained by $0.01 \mathrm{M} \mathrm{CH}_{3} \mathrm{COOH}$ leaching at liquid/solid ratio of 250 is shown in Table 2. Zincite is completely removed and more than $99 \%$ of iron remains in the solid residue.

Table 2 Mineralogical composition of the sludge and the solid residue obtained by $0.01 \mathrm{M} \mathrm{CH}_{3} \mathrm{COOH}$ leaching (wt.\%)

\begin{tabular}{|c|c|c|}
\hline & Sludge & Residue \\
\hline Magnetite & 35 & 40 \\
\hline Wuestite & 4 & 5 \\
\hline Hematite & 3 & 3 \\
\hline Franklinite & 52 & 50 \\
\hline Zincite & 5 & 0 \\
\hline Graphite & 1 & 2 \\
\hline
\end{tabular}

Only a small part of zinc ferrite can be dissolved in acetic acid (Figure 7). The compound probably contains some portion of $\mathrm{ZnO}$ and so the selectivity is greater than 1. Ferric acetate is almost insoluble in water so it may precipitate after the zinc ferrite dissolution.

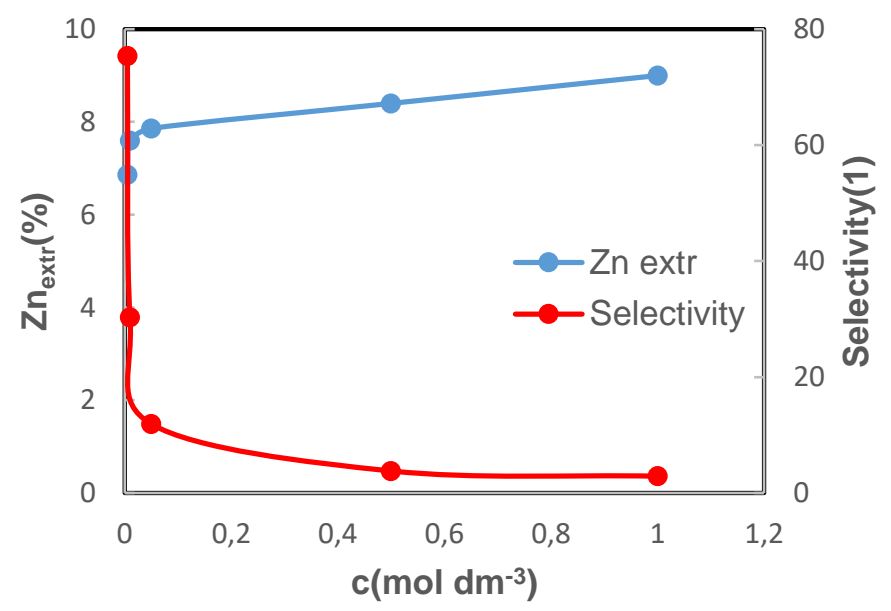

Figure 7 Concentration dependence of metal extraction from $\mathrm{ZnFe}_{2} \mathrm{O}_{4}$ in $50 \mathrm{ml}$ of acetic acid after 3 hours 


\section{CONCLUSION}

Acetic and butyric acid were used for leaching of the steel-making sludge and zinc ferrite. Zinc contained in zincite can be extracted almost selectively using diluted acetic acid. The selectivity decreases with the increasing acid concentration, increasing liquid/solid ratio and time. The best results were obtained for $0.01 \mathrm{M}$ acetic acid, solid/liquid ratio 250-500 and1-3 hours. No significant improvement was reached using butyric acid. Preliminary experiments suggest that the leach liquor can be used for the preparation of photocatalyst. The solid residue consists mainly of zinc ferrite and magnetite. This material will be studied with the view of preparation of hybrid nanocomposites with special magnetic properties and of catalysts.

\section{ACKNOWLEDGEMENTS}

This work was financially supported by the project "Research on the management of waste, materials and other products from metallurgical and related sectors", CZ.02.1.01/0.0/0.0/17_049/0008426 and by the project of Specific research: SP 2019/142

\section{REFERENCES}

[1] STEFANOVA, A., AROMAA, J., FORSEN, O. Alkaline leaching of zinc from stainless steel electric arc furnace dusts. Physicochemical Problems Mineral Processing. 2015, vol. 51, pp. 293-302.

http://dx.doi.org/10.5277/ppmp150126

[2] JHA, M.K., KUMAR, V., SINGH, R.J. Review of hydrometallurgical recovery of zinc from industrial wastes. Resources, Conservation and Recycling. 2001, vol. 33, pp. 1-22.

[3] AL-MAKHADMEH, L.A., BATIHA, M.A., AL-HARAHSHEH, M.S., ALTARAWNEH, I.S., RAWADIEH, S.E. The Effectiveness of Zn Leaching from EAFD Using Caustic Soda. Water Air Soil Pollution. 2018, vol. 229, pp. 33-43. https://doi.org/10.1007/s11270-018-3694-4.

[4] LANGOVÁ, Š., RIPLOVÁ, J., VALLOVÁ, S. Atmospheric leaching of steel-making wastes and the precipitation of goethite from the ferric sulphate solution. Hydrometallurgy. 2007, vol. 87, no. 3-4, pp. 157-162.

[5] HALLI, P., HAMUYUNI, J., REVITZER, H., LUNDSTR€OM, M. Selection of leaching media for metal dissolution from electric arc furnace dust. Journal of Cleaner Production. 2017, vol. 164, pp. 265-276. http://dx.doi.org/10.1016/j.jclepro.2017.06.212.

[6] PARK, S.J., SON, I., SOHN, H.S. Leaching of Zinc from EAF Dust by Sulfuric Acid. Korean journal of metals and materials. 2015, vol. 53, pp.793-800. https://doi.org/10.3365/KJMM.2015.53.11.793.

[7] WANG, J., WANG, Z., ZHANG, Z., ZHANG, G. Removal of zinc from basic oxygen steelmaking filter cake by selective leaching with butyric acid. Journal of Cleaner Production. 2019, vol. 209, pp. 1-9.

https://doi.org/10.1016/i.jclepro.2018.10.253.

[8] LANGOVÁ, Š., MATÝSEK, D. Zinc recovery from steel-making wastes by acid pressure leaching and hematite precipitation. Hydrometallurgy. 2010, vol. 101, pp. 171-173.

[9] HOLLOWAY, P.C., ETSELL, T.H., MURLAND, A.L. Modification of Waelz kiln processing of La Oroya zinc ferrite. Mining, Metallurgy \& Exploration. 2008, vol. 25, pp. 97-104.

[10] PICKLES, C.A. Thermodynamic analysis of the separation of zinc and lead from electric arc furnace dust by selective reduction with metallic iron. Separation and Purification Technology. 2008, vol. 59, pp. 115-128.

[11] GAO, J., CHENG, F. Effect of Metal Substitution on the Magnetic Properties of Spinel Ferrites Synthesized from Zinc-Bearing Dust. Journal of Superconductivity and Novel Magnetism. 2018, vol. 31, pp.1965-1970. https://doi.org/10.1007/s10948-018-4690-z.

[12] SU, C. Environmental implications and applications of engineered nanoscalemagnetite and its hybrid nanocomposites: A review of recent literature. Journal of Hazardous Materials. 2017, vol. 322, pp. 48-84. http://dx.doi.org/10.1016/j.jhazmat.2016.06.060. 